\title{
Creating Digital Anti-Corruption Message Based on Pancasila Values through Documentary Films: Learning from Students' Experience
}

\author{
Hendar Putranto \\ Communication Science Department \\ Universitas Multimedia Nusantara \\ Tangerang, Indonesia \\ hendar2007@umn.ac.id
}

\author{
Rony Agustino Siahaan \\ Communication Science Department \\ Universitas Multimedia Nusantara \\ Tangerang, Indonesia \\ rony@umn.ac.id
}

\begin{abstract}
Today's world is highly saturated with digital experience and the state of learning social phenomena is also seen through the eyes of the lens, namely mediated communication. Countering the illness of society, such as corruption, based on Pancasila values, should also take this digital approach into consideration. Students of today are no longer confined within the camp of textbook and classroom activity if they want to immerse themselves in digital sphere, to create and express their knowledge and perception of surroundings. Bloom's digital taxonomy as tools to facilitate learning, if employed passionately, would be an advantage for students to convey Anti-corruption message in virtually attractive ways and to move their affection into well-built characterization of responsible citizens of tomorrow.
\end{abstract}

Keywords-mediated communication; digital anti-corruption message; Pancasila values; Ploom's digital taxonomy; phenomenology of values

\section{INTRODUCTION}

Indonesia is perceived as a country with high index of corruption, especially for the last four years (2014-2017) [1]. Mass media and social media prolific reportage on the issue of corruption is contributing positively towards society's perception on the issue as cancerous for the quality of public service. Unfortunately, even though phenomena of corruption has been portrayed at large by various media, and been discussed by several fields of social studies, nevertheless, there is no single research-based publication found on the issue of corruption which is combining quantitative-empirical research with theory of values and social constructivist learning. This research attempts to address the gap by mapping students' understanding about corruption with their awareness of Pancasila values and how to make the understanding explicit by producing digital video items. Hypothetically, the seeds of corruption can be detected in school since students come into contact with variety of values (from family, religion, mass media, school, friendship, and many others) which is not always in harmony with each other.

Recently, the general trend of mentioning and discussing Pancasila-related topic is on the rise, due to apparent threat from terrorism, fundamentalism-based social movement, and various threats towards diversity (kebhinnekaan) as values. Unfortunately, very few public figures, nor mass media, address issues of Pancasila, nationalism, and diversity by linking them with another highly important public issue, that is, eradication and prevention of corruption. If Pancasila as the highest ideal norms for each and every Indonesian citizen is perceived as capable to link-and-match any national-interest topics and discourses, corruption seems elusive from its reach. The current study wants to highlight that missing point and underline its significance for nation-building project.

Two sets of study on Anti-Corruption Pedagogy in school and youth perception on corruption are published before this current research. First, a study by Sabrina O. Sihombing and Rudy Pramono [2] and second, by Kokom Komalasari and Didin Saripudin [3]. Sihombing and Pramono [2] are more focused on how to understand frame of values shared by youth in Indonesia recently, and linked with corruption as phenomena. Sihombing and Pramono shared the opinion that, "corruption is perceived by youth as domestic problem." Sihombing and Pramono did not specifically address youth as students from senior high schools. Komalasari and Saripudin [3] highlights more on the descriptive side of anti-corruption curriculum content found in Citizenship Study (Pendidikan Kewarganegaraan), based on 2006 national curriculum. They also re-introduce anti-corruption pedagogy developed by KPK, intended for junior and senior high school students. The pedagogy consists of nine values, namely honesty, hard work, discipline, bravery, responsibility, independence, moderation, justice and caring as basic values to shape anti-corruption character. Nevertheless, Komalasari and Saripudin did not make explicit how to link and match those nine basic values with Pancasila values as Indonesian citizens' core values as well as nation's formal ideology.

Previous research by Hendar and Rony in 2017 employed a different strategy to approach and to evaluate students' perception on Pancasila values and its relatedness with anticorruption issue. Students' perception is measured through structured and categorized 14-items questionnaire, and the overall results were then quantified by using SPSS method. The publication based on this has been currently under review process in Jurnal Humaniora (UGM). Meanwhile, this current 
research project (2018) is predominantly based on last year research project with more result-oriented on multimedia projects produced by students from 8 selected schools: 4 schools from Banten Province and 4 schools from DKI Jakarta Province.

\section{MethodS}

The series of workshops we are currently engaged is part of two years research project titled "The Development of Educational Module on Pancasila-values based Anticorruption Attitudes and Actions”. Having previously taken survey and FGD as mixed methods in 2017, we are now conducting series of multimedia production workshops with specific target to produce, namely documentary films, titled "Senior High School Students; Learning Process on Anticorruption Behavior based on Pancasila Values." Workshops are taking place in several Senior High Schools in Banten and Jakarta which have been previously surveyed. Each workshop conducted in each high school represents a unique case study. As the main target, we will generate 8 single cases from 8 different schools. By doing this, the character of research methodology in our current project is multiple case study, with similar unit analysis, namely students' learning process on anticorruption behavior through activity of producing documentary films.

Why are we using documentary films and digital landscape to express youth understanding on both anticorruption and Pancasila values' issue? In his foreword to a seminal book authored by Carrie James titled "Disconnected" [4], Henry Jenkins, a renowned cultural critic of digitalization and digital society, says that teens' active digital lives should not worry us overtly, but rather, be embraced with what it offers in abundance: freedom and responsibility. According to Jenkins, "the online world is neither an ideal society nor hell on earth. Rather, the online world is a place where we conduct routine aspects of our daily lives, and often we think less than we should about the consequences of the choices we are making there... more needs to be done to support our young people's moral development in the digital age. I care very much about the issues James raises here because I believe that our goal should be to expand who has access to the means of cultural production, circulation, and participation [4, pp. 14-15]

Seen from the perspective of Benjamin Bloom's Taxonomy of Learning, which has been currently updated to covering Digital Taxonomy, students' activity to engage in this workshop is part of learning process called "creating knowledge," with "filming, video casting, and directing" as specific verbs related with this domain, as portrayed in this picture below.

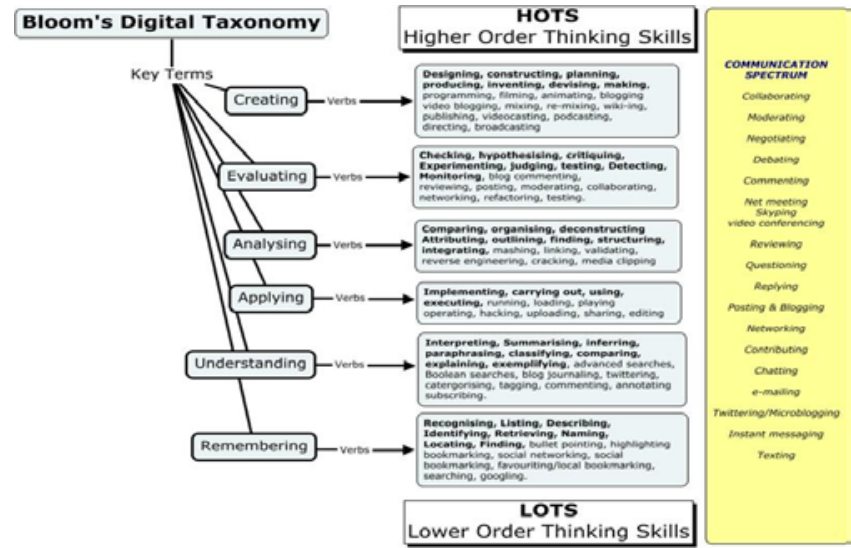

Fig. 1. Bloom's Digital Taxonomy

This workshop activity is also confirming the paradigm of Student-Centered Learning in which knowledge is no longer transmitted from Instructor (teacher), but rather constructed by students, which can be seen in Image 2 below. By making documentary film, students find and construct their own practical knowledge about what it takes to show anticorruption behavior. By employing these strategies and paradigm, scientific approach used in this workshop-as learning method-is a constructivist approach.

\section{TEACHER-CENTERED vS STUDENT- CENTERED LEARNING}

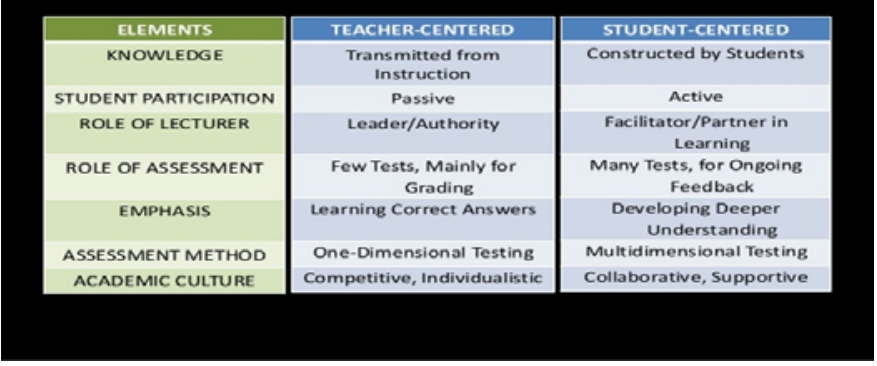

Fig. 2. Teacher-Centered vs. Student-centered Learning

Constructivist approach is built upon the assumption that subjective reality is constructed by individual agent through experiences he/she engages in his/her surroundings. When those experiences become his/her source of reference for thinking and foundation for action, that subjective reality is then established as knowledge. According to a renowned social learning psychologist, Vygotsky, students learn from each other; they can assist one another and co-construct knowledge. This knowledge and cognitive development gathered by learner is equal to social awareness. By other words, knowledge is produced through social sources and context within the learner's environment. Constructivist approach used in this project is employed strategically through students' experience while engaging in documentary filming activity. Before embarking upon videography activity (recording, filming), the 6 participants (students) are grouped in two wherein one group consists of three students, so that the students who understand the issue better can work with the students who do not properly understand. The student who better understands' phrasing might make more sense to the other students. The more knowledgeable student would also learn something from this 
group activity, perhaps a deeper understanding of the content or a way to explain the concept that they had not thought of before.

Students 'construct' their own meaning by building on their previous knowledge and experience, both on Pancasila values and corruption phenomena. New ideas and experiences are purposively countered against existing (taken for granted) knowledge, and the learner constructs new or adapted rules to make sense of the world. Facilitator's role is merely proposing the issue in the realm of students' accepted knowledge and they will, by assistance, come to articulate their learning process in such a way as to be called "their own constructs of the world." [5].

By following Berger and Luckmann’ reality construction stages, namely externalization, objectivation and internalization, this workshop is within the stage of externalization. In this stage, students are showing their best efforts to search and find knowledge through documentary production process which gradually move from pre-production, production, and post-production.

Employing constructivist approach, students as workshop participants are perceived and treated as research partners. They are actively participating during the whole process of production required by workshop and guided by researchers as facilitator. Their own experiences while immersing in production process will be inserted into their documentary film as part of learning model to be catalogued later as anticorruption knowledge. While their story content of documentary film will later be developed as materials for creating anticorruption educational module for senior high school curriculum.

Data gathering is conducted through participationobservation technique, following three stages of production process: pre, production and post. In this manner, researchers are taking the role of facilitator who helps to realize the documentary process of the students. Students' activity in the team when discussing ideas, topics and storylines of their would-be documentary film become pre-production activity data. Students' activity in doing interviews and taking shoots, technically assisted by researchers' assistants (hired university students), become production activity data. Meanwhile, pictures and shoots editing process as well as overarching storylines worked upon by students and research assistants will become post-production activity data.

\section{RESULTS AND DISCUSSION}

Taking 'reality' and 'knowledge' for granted without troubling oneself is a character of knowledge produced by man in the street [6, p. 14]. Wherein "the reality of everyday life further presents itself to me as an intersubjective world, a world that I share with others...I cannot exist in everyday life without continually interacting and communicating with others. [6, p. 37] is a life-world shared by researchers and students alike during the workshops. Knowing these principles of constructed reality as paradigm to act upon, Pancasila values (divinehood, humanity, unity, people deliberative assembly, social justice) are articulated accordingly during workshops, in relation with anticorruption issues and the shaping of students' attitudes.
Students' documentary projects will become authentic evidence of their efforts in understanding corruption as phenomena and in building their behavior against corruption. This documentary project is likely to show their different perception on the same "reality" of corruption and Pancasila values, compared with their peers who do not engage in workshops. The difference mainly lies in the level of active participation and deliberate efforts to understand what is meant by corruption in school setting, or, at least, seeds of corruption in the acts of dishonesty (cheating in exam, for example). Survey in 2017 shows that students' perception towards corruption is predominantly influenced by reality as portrayed by social media and mass media, thus, mediated reality.

In this "mediated reality as the main source," students' knowledge and understanding about corruption in particular and Pancasila values in general, are passive observational. They are not producers of meaning and agents of knowledge. Their level of engagement towards articulating the issue at hand is perceptive at best, not transformative. By engaging in documentary workshops, the learning process has taken another turn. They are no longer passive learners trying to comprehend reality "out there" but rather, active participants making their own articulated, though limited, knowledge and reality. Their serious efforts to discuss Pancasila values, to sharpen their perception on the seeds of corruption hidden behind "normal reality of school setting" is a living knowledge ready to transform their system of values on social constructed reality. One instance stands out from one of the pre-production workshops. One particular student enrolled in state school felt that the "illegal fee" collected by school at the beginning of new semester without any transparency where the fees go (allocated) afterwards is a sample of corruption in school setting. His previous knowledge about corruption in school after watching a documentary published in YouTube titled “Aksi Berani Murid SMA 3 Surakarta Membongkar Korupsi Gurunya” (Valor act of Students in SMA 3, Surakarta, in Dismantling Teachers' Corruption) [7] confirms his belief to engage more seriously in producing documentary film by his own meaning-making, co-construct along with his team.

\section{CONCLUSION}

When discussing about social movement and social transformation in digital age, such as represented by empowering the use and roles of websites and social media in shaping people's preferences for social change, the lessons taken from survey conducted in the first year of research are optimistic at best. Teenagers born in 2000's (millennial generations) are less likely to adopt old techniques of absorbing and implementing Pancasila values, but they are more likely and hopeful to become the agents of change in making Indonesia great again (zero corruption). Teenage students now are the likely producers of information in the future: while social media is participatory, thus preferable for millennials generation, website is more static as source of information. Their thoughts on ideal values embedded within Pancasila, and one of its enemies in the name of corruption, should be well articulated by using their own preferred techniques, namely, producers of meaning through the eyes of the lens (photography and videography). 


\section{REFERENCES}

[1] “Indonesia Corruption Index," in Trading Economics. [Online]. Available: https://tradingeconomics.com/indonesia/corruption-index.

[2] S. O. Sihombing and R. Pramono, "Indonesian Youth Values and Corruption: A Descriptive Study,” presented at the 1st NCBMA in Pelita Harapan Univ., Tangerang, Indonesia, Mar. 19, 2015.

[3] K. Komalasari, and D. Saripudin, "Integration of Anti-Corruption Education in School's Activities,” in American J. of Appl. Sci., vol. 12, no. 6, pp. 445-451, 2015. DOI: 10.3844/ajassp.2015.445.451

[4] C. James, Disconnected: Youth, New Media, and the Ethics Gap. Cambridge, Massachusetts and London, England: The MIT Press, 2014.
[5] "Education Theory: Constructivism and Social Constructivism," in Open Educational Resources of UCD Teaching and Learning, University College Dublin. [Online]. Available: http://www.ucdoer.ie/index.php/Education_Theory/Constructivism_and Social_Constructivism.

[6] P. L. Berger and T. Luckmann, The Social Construction of Reality: A Treatise in the Sociology of Knowledge. London and New York: Penguin Books, $1966 . \quad$ [Online]. Available: http://perflensburg.se/Berger\%20social-construction-of-reality.pdf [Accessed June 20, 2018].

[7] drestaJumena, “Aksi Berani Murid SMA 3 Surakarta Membongkar Korupsi Gurunya [Valor act of Students in SMA 3, Surakarta, in Dismantling Teachers' Corruption],” August 16, 2016. [Online]. Available: https://www.youtube.com/watch?v=6u4guDaFjX8. 